\title{
食餌性肥満モデルマウスにおける肝臓脂質蓄積および軽度炎症に及ぼす ロイシンとバリンの効果
}

Effect of leucine and valine supplementation on liver lipid accumulation and proinflammation in diet-induced obese mice

工藤 陽香 $^{1}$, 山中 千恵美 ${ }^{1}$, 青江 誠一郎 $^{2}$

${ }^{1}$ 大妻女子大学大学院 人間文化研究科, ${ }^{2}$ 大妻女子大学 家政学部

Haruka Kudo ${ }^{1}$, Chiemi Yamanaka ${ }^{1}$, and Seiichiro Aoe $^{2}$

${ }^{1}$ Graduate School of Studies in Human Culture, Otsuma Women's University

12 Sanban-cho, Chiyoda-ku, Tokyo, Japan 102-8357

${ }^{2}$ Faculty of Home Economics, Otsuma Women's University

12 Sanban-cho, Chiyoda-ku, Tokyo, Japan 102-8357

キーワード : 分岐鎖アミノ酸, 肝臓脂質，酵素活性

Key words : Branched-chain amino acids, Liver lipid accumulation, Enzyme activity

\section{一 抄録}

近年，肥満の増加に伴い，併発する頻度の高い非アルコール性脂肪肝(NAFLD)が着目されている. 日本での NAFLD 有病率は約 30\% と報告されており, 今後さらに増加していくと予測されている. 分 岐鎖アミノ酸(BCAA)は以前より骨格筋合成促進作用があるとされサプリメント等で使用されてきた が, 近年脂肪蓄積抑制作用があると報告されている.そこで, 食餌性肥満モデルマウスにおける BCAA の肝臓脂質蓄積への影響について検討を行った。飼料は AIN-93G 組成を基本とし，20\%カゼインを コントロール(CO 群), $\mathrm{BCAA}(12 \%$ ロイシン，5\%バリン)を強化した群(LV 群)とした. また, 脂肪エ ネルギー比が $50 \%$ となるようラードを添加し，5 週齢雄の C57BL/6J マウスに 12 週間給餌した. その 結果, 肝臟トリグリセリド蓄積量がコントロールと比較して有意に低下した. 肝臓の mRNA 発現を 測定したところ，脂質合成系の転写調節因子であるステロール調節エレメント結合たんぱく質 -1c(SREBP-1c)および脂肪酸合成酵素(FAS), および脂質分解系の転写調節因子であるペルオキシゾー ム増殖剂応答性受容体 $\alpha(\mathrm{PPAR} \alpha)$ およびその下流のアシル CoA 酸化酵素(ACOX), 並びに炎症マーカ 一の発現に有意な差は見られなかった. しかし, 酵素活性を測定した場合, CO 群と比べて LV 群で FAS 活性について有意差は見られなかったが，ACOX ではコントロールと比較して BCAA 添加で有 意に高值を示した．以上の結果より，ロイシンとバリンの添加により ACOX を活性化させ $\beta$ 酸化の 活性を高めることで肝臓脂肪蓄積を抑制する可能性が示された.

\section{1. 序論}

2008 年 4 月より，メタボリックシンドロームに 着目した特定健診・特定保健指導が実施され, そ れに伴い, メタボリックシンドロームにおいて併 発する頻度の高い非アルコール性脂肪肝(NAFLD) が着目され始めた. 日本での NAFLD 患者数は約 1000 万人とされており, 今後さらに増加していく と予測されている. 肝細胞にトリグリセリドが蓄 積し，そこに酸化ストレスなどが曝露すると炎症 を起こし，非アルコール性脂肪肝炎(NASH) となり，
進行すると不可逆性の肝硬変, 肝細胞ガンへと発 展する。つまり, 肝臓の脂質蓄積, 炎症を抑制す ることがNASH 抑制に対して有効である.

分岐鎖アミノ酸(BCAA)とは, 必須アミノ酸であ るバリン，ロイシン，イソロイシンを指す. BCAA は以前より骨格筋合成促進効果が知られ[1]，今日 ではBCAA サプリメントとしても販売されている が，近年では肥満マウスにおける体重減少や脂質 代謝にも影響を及ぼすことが報告されている

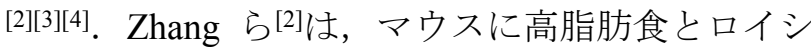


ンを同時投与すると, 食餌誘発性肥満, 高血糖, 血清コレステロール濃度の上昇を抑制したと報告 しており，これは，骨格筋中脱共役たんぱく質 (UCP)の発現増加による安静時エネルギー消費量 の増加に伴う体脂肪量の減少が関係していると推

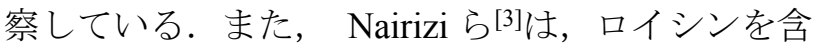
有させた水を摂取させることにより, 高脂肪食に よる体重増加を抑制すると報告している。ささらに, Macotela ら ${ }^{[4]}$ は，高脂肪食におけるロイシン添加 は, 脂肪酸合成酵素(FAS)やアセチル CoA カルボ キシラーゼ(ACC)の発現を抑制することにより， 肝臓脂質の蓄積を抑制したことを報告している。 イソロイシンにおいては耐糖能を改善する作用が 多く報告されている。そのメカニズムとして，骨 格筋においてインスリンが関与していない状態に おいても PI-3 キナーゼを刺激し，グルコーストラ ンスポーター4(GLUT4)を細胞膜へ移行させ，イン スリン非依存的なグルコースの取り込みを促進す ることが提唱されている。近年では，イソロイシ ンは筋肉および肝藏においてペルオキシゾーム増 殖剂応答性受容体 $\alpha($ PPAR $\alpha)$ およ゙ UCP の発現を 増加させることで脂質蓄積を抑制するという報告 もある[5]. バリンについては，脂質蓄積抑制およ び NAFLD に伴う慢性炎症への影響に関する報告 は少ない。

NAFLD になり肝臟にトリグリセリドが蓄積す ると, 活性酸素による酸化ストレスによって炎症 マーカーの発現が促進され, 炎症が惹起されるこ とが知られている。 BCAA と炎症については, BCAA は四塩化炭素によって肝硬変を誘導したラ ットにおいて，抗酸化作用を有するタンパク質の 発現増加および活性酸素の減少により, 酸化ス卜 レスを軽減させ寿命も延長させたという報告があ る[6].また，脂質が蓄積されることで活性酸素が 発生し, 酸化ストレスが増大寸ることで炎症マー カーが増加し，軽度炎症が誘導される.

著者はこれまでの研究により, アミノ酸混合物 を摂取させたラットの門脈中にバリンとロイシン がコントロール飼料摂取群と比べて多く検出され たことを確認している(未発表データ). そこで本研 究では，バリン，およびロイシンの添加が食餌性 肥満モデルマウスの肝臓脂質蓄積および，軽度炎 症に及ぼす効果について検討した.

\section{2. 方法}

\section{1 実験動物}

5 週齢雄の C $57 \mathrm{BL} / 6 \mathrm{~J}$ マウス(日本チャールス・リ バー株式会社)を 20 匹用いた。 固形飼料（NMF; 才 リエンタル酵母工業株式会社）を用い，1 週間の 予備飼育後, 体重が均一になるように 1 群 10 匹ず つ 2 群(CO 群，LV 群)に群分けし，12 週間飼育し た。飼育期間中，飼料と水は自由摂取とした。マ ウスは，室温 $22 \pm 1^{\circ} \mathrm{C}$ ，湿度 $50 \pm 5^{\circ} \mathrm{C} ， 12$ 時間明暗 サイクル(昼 7:00 19:00)で飼育した。

\section{2 実験飼料}

飼料組成を Table 1 に示す。

コントロール(CO)群の飼料は AIN-93G 組成を基 本とし，脂質エネルギー比が $50 \%$ となるよう，ラ ードを添加し高脂肪食とした。コントロール群 (CO 群)のたんぱく質源はカゼイン $20 \%$ とし， ロ イシンおよびバリン群(LV 群)は 12\%ロイシンおよ び 5\%バリンを添加しカゼインと置換した. 各群の たんぱく質，脂質量が等しくなるように，たんぱ く質量はカゼイン，脂質量は大豆油，ラードで調 整した。 大豆油，重酒石酸コリン， $t$-ブチルヒドロ キノン，L-ロイシン，L-バリンは和光純薬工業株 式会社，ラードは植田製油株式会社より購入した。

Table 1． 飼料組成 $(\mathrm{g} / \mathrm{kg})$

\begin{tabular}{lrr}
\hline & CO群 & \multicolumn{1}{c}{ LV群 } \\
\hline カゼイン & 200.0 & 187.9 \\
ロイシン & - & 12.08 \\
バリン & - & 5.05 \\
L-シスチン & 3.0 & 3.0 \\
コーンスターチ & 55.5 & 50.4 \\
aコーンスターチ & 264 & 264 \\
ショ糖 & 100 & 100 \\
大豆油 & 70 & 70 \\
ラード & 200.0 & 200.0 \\
セルロース & 50.0 & 50.0 \\
AIN-93G特殊ミネラル混合* & 35 & 35 \\
CaCO & 10.0 & 10.00 \\
AIN-93Gビタミン混合 & 10 & 10 \\
重酒石酸コリン & 2.5 & 2.5 \\
$t$-ブチルヒドロキノン & 0.014 & 0.014 \\
\hline 飼料中ロイシン & 16.8 & 27.8 \\
\multicolumn{1}{c}{ バリン } & 12.0 & 16.7 \\
\hline “CaCOsを含。ない & &
\end{tabular}

${ }^{*} \mathrm{CaCO}_{3}$ を含まない

CO:コントロール，LV:ロイシン+バリン 


\section{3 動物解剖とサンプル採取}

解剖当日，イソフルラン $/ \mathrm{CO}_{2}$ ガス深麻酔下で開 腹し, 心藏より採血した後, 肝臓, 後腹壁脂肪組 織, 副睪丸周辺脂肪組織および腸間膜脂肪組織を 摘出し，重量を測定した。血液は $38 \times 100 \mathrm{~g}, 4^{\circ} \mathrm{C}$ で 15 分間遠心分離し, 血清を $-80^{\circ} \mathrm{C}$ で保存した. 肝臓 は- $20^{\circ} \mathrm{C}$ で保存した. 本実験は大妻女子大学家政学 部動物実験において定められた「実験動物施設の 整備および管理の方法ならびに具体的な実験方法 を定めた規則」に則り，倫理審査委員会の承認を 得て行った.

\section{4 分析方法}

(1)血清生化学值

血清は，トリグリセリド，遊離脂肪酸，総コレ ステロール濃度は酵素法にて分析した。 トリグリ セリドの定量には「トリグリセライド E-ワコー」, 遊離脂肪酸(NEFA)の定量には「NEFA C-テストワ コー」, 総コレステロール濃度の定量には「コレス テロールE-ワコー」(いずれも和光純薬工業株式会 社)を使用した。血清インスリン濃度は,「レビス インスリン-ラット $(\mathrm{H}$ タイプ $) 」($ 株式会社シバヤギ $)$ を用い, ELISA 法にて分析した。

血中グルコース濃度測定は，6時間の絶食後, 無麻酔下で尾静脈から採血し, 「小型血糖測定器 グルテストエース R」(株式会社三和科学研究所) を用い電極法にて測定した。

\section{(2)肝臓脂質および mRNA 発現}

肝臓脂質の分析は, 肝臓を凍結乾燥後, 粉砕し, クロロホルム:メタノール(2:1)溶液を用いた Folch 法により抽出, 水洗, 乾固後, ドラフト内で窒素 気流下によって溶媒を除去 $\left(60^{\circ} \mathrm{C}\right)$ し， 10\%TritonX-100 を含むイソプロパノールを加えて 溶解し, トリグリセリド, 総コレステロール濃度 を酵素法にて分析した。トリグリセリドの定量お よび総コレステロールの定量は, 前出の血清生化 学值法と同じである.

肝臓の mRNA 発現量の測定は, RNeasy Mini kit(株式会社 Qiagen)を用いて総 RNA 量をプロトコ ールに準じて抽出し, 総 RNA 量を $260 \mathrm{~nm}$ の吸光 度から求めた。抽出した RNAを用いて逆転写ポリ メラーゼ連鎖反応(RT-PCR)を行い, mRNA 発現量 の測定に用いた.mRNAの発現量は7300 Real-Time PCR System (Applied Biosystems) を用いて, SYBR Green 法にて行い, 内部標準として用いた 36B4 と
の相対比により求めた。測定項目とプライマー配 列を Table 2 に示寸.

Table 2. プライマー配列

\begin{tabular}{lll}
\hline \multicolumn{2}{c}{ Forward } & Reverse \\
\hline SREBP-1c & 5'-GGCACTAAGTGCCCTCAACCT-3' & 5'-GCCACATAGATCTCTGCCAGTGT-3' \\
FAS & 5'-CCTGGATAGCATTCCGAACCT-3' & 5'-AGCACATCTCGAAGGCTACACA-3' \\
PPARa & 5'-AGGAAGCCGTTCTGTGACAT-3' & 5'-AATCCCCTCCTGCAACTTCT-3' \\
ACOX & 5'-CAGCGTTACGAGGTGGCTGTTA-3' & 5'-TGCCCAAGTGAAGGTCCAAAG-3' \\
mtGPAT & 5'-ACAGTTGGCACAATAGACGTTT-3' & 5'-CCTTCCATTCAGTGTTGCAGA-3' \\
TNF- $\alpha$ & 5'-ACCCTCACACTCAGATCATCTTC-3' & 5'-TGGTGGTTTGCTACGACGT-3' \\
p40 $0^{\text {phox }}$ & 5'-CAGCCAACATCGCTGACATC-3' & 5'-CAAAGTGGCTGGTGAAGCCT-3' \\
p47 $7^{\text {phox }}$ & 5'-ACTCTCACTGAATACTTCAACG-3' & 5'-TCATCAGGCCGCACTTT-3' \\
p67 $7^{\text {phox }}$ & 5'-AAGCAAAAAGAGCCCAAGGAA-3' & 5'-CATGTAAGGCATAGGCACGCT-3' \\
36 B4 & 5'-GGCCCTGCACTCTCGCTTTC-3' & 5'-TGCCAGGACGCGCTTGT-3' \\
\hline
\end{tabular}

(3) 肝臓の脂肪合成系酵素 (FAS) - 分解系酵素 (ACOX)の比活性の測定

肝臟約 $0.5 \mathrm{~g}$ に $0.25 \mathrm{M}$ Sucrose, $1 \mathrm{mM}$ EDTA, $3 \mathrm{mM}$ トリス塩酸( $\mathrm{pH} 7.2)$ を加えホモジナイズ後, $5 \times 100 \mathrm{~g}$ で 10 分間, $4{ }^{\circ} \mathrm{C}$ で遠心分離した。 上清 $(\mathrm{ACOX}$ の測 定で使用)を採取し, さらに $7,500 \times \mathrm{g}$ で 10 分間, $4^{\circ} \mathrm{C}$ で遠心分離することにより，ミトコンドリア画分 を沈殿させ，上清(FAS の測定で使用)を採取した。 セル内のたんぱく質濃度は，プロテインアッセイ キット II (日本バイオ・ラッド ラボラトリーズ株 式会社)を用いて Bradford 法により測定した。

脂肪酸合成酵素(FAS)の比活性測定は, サイトソ ル画分を用いて Kelly ら ${ }^{[7]}$ の方法で測定を行った. アシル CoA オキシダーゼ(ACOX)の比活性測定は 総ホモジネートを用いて Hashimoto ら ${ }^{[8]}$ の方法で 測定を行った。

\section{5 統計解析}

すべての測定結果は平均值土標準偏差で示した. Shapiro-Wilk の正規性の確認と Bartlett の等分散検 定を行い，等分散性が確認できた場合は $\mathrm{t}$ 検定を 行った。不等分散の場合の多重比較は, Wilcoxon の検定を用いた。統計解析は JMP Pro 12 (SAS Institute 社) を用いた。有意水準は両側 $5 \%$ 未満と した.

\section{3. 結果}

終体重, 体重増加量, 飼料摂取量, 飼料効率, 肝臓重量および各脂肪組織重量において, CO 群と LV 群の間に有意差は見られなかった(Table 3). 
Table 3. 成長結果および臓器重量

\begin{tabular}{lcc}
\hline & CO群 & LV群 \\
\hline 終体重 $(\mathrm{g})$ & $41.0 \pm 4.0$ & $37.8 \pm 4.0$ \\
体重増加量(g/day) & $0.26 \pm 0.05$ & $0.22 \pm 0.05$ \\
飼料摂取量(g/day) & $2.2 \pm 0.2$ & $2.4 \pm 0.2$ \\
飼料効率(\%) & $11.7 \pm 1.5$ & $9.9 \pm 1.7$ \\
肝臓重量(g) & $1.2 \pm 0.2$ & $1.1 \pm 0.2$ \\
後腹壁脂肪組織重量 $(\mathrm{g})$ & $1.1 \pm 0.4$ & $0.9 \pm 0.2$ \\
副睪丸周辺脂肪組織重量(g) & $2.5 \pm 0.5$ & $2.2 \pm 0.5$ \\
腸間膜脂肪組織重量(g) & $0.8 \pm 0.4$ & $0.6 \pm 0.2$ \\
\hline 数
\end{tabular}

数值は平均值 \pm SDで表した。

$\mathrm{CO}$; コントロール，LV；ロイシン+バリン

血清トリグリセリド濃度，血清総コレステロー ル濃度, 血清遊離脂肪酸濃度, インスリン濃度に ついて CO 群と LV 群の間に有意差は見られなかつ た(Table 4).

Table 4. 血清生化学值およびインスリン濃度, 血 糖值

\begin{tabular}{lcc}
\hline & CO群 & LV群 \\
\hline トリグリセリド $(\mathrm{mg} / \mathrm{dl})$ & $82.2 \pm 16.1$ & $87.9 \pm 18.7$ \\
総コレステロール $(\mathrm{mg} / \mathrm{dl})$ & $155.1 \pm 37.5$ & $146.6 \pm 42.3$ \\
遊離脂肪酸 $(\mathrm{mEq} / \mathrm{l})$ & $0.47 \pm 0.10$ & $0.51 \pm 0.09$ \\
インスリン $(\mathrm{ng} / \mathrm{ml})$ & $36.8 \pm 12.1$ & $43.2 \pm 10.6$ \\
グルコース $(\mathrm{mg} / \mathrm{dl})$ & $177.1 \pm 27.3$ & $179.6 \pm 26.6$ \\
\hline 数值は平均值 $\pm \mathrm{SD}$ で表した。 & \\
$\mathrm{CO}$; コントロール $\mathrm{LV} ;$ ロイシン+バリン &
\end{tabular}

肝臓トリグリセリド蓄積量は CO 群と比べて LV 群で有意に低下したが，総コレステロール蓄積量 に有意差は見られなかった(Table 5).

Table 5. 肝臓脂質蓄積量 $(\mathrm{mg})$

\begin{tabular}{lcc}
\hline & CO群 & LV群 \\
\hline トリグリセリド(肝臓1g当たり) & $58.3 \pm 21.0$ & $39.6 \pm 7.9^{*}$ \\
トリグリセリド(肝臓全体) & $67.8 \pm 27.9$ & $44.0 \pm 12.3^{*}$ \\
コレステロール(肝臓1g当たり) & $6.3 \pm 1.5$ & $6.8 \pm 1.7$ \\
コレステロール(肝臓全体) & $7.2 \pm 1.5$ & $7.5 \pm 2.8$ \\
\hline
\end{tabular}

数值は平均值 $\pm \mathrm{SD}$ で表した

${ }^{*} \mathrm{CO}$ 群と比べて有意差あり $(\mathrm{p}<0.05)$

$\mathrm{CO}$; コントロール, LV ; ロイシン+バリン

肝臓の mRNA 発現は，炎症マーカーである腫瘍 壊死因子- $\alpha(\mathrm{TNF}-\alpha)$, およびNADPH オキシダーゼ のサブユニットである p40 phox, p47phox, p67phox, 脂質代謝関連酵素の転写因子であるステロール調 節エレメント結合たんぱく質 1c (SREBP-1c), ペ ルオキシゾーム増殖剤応答性受容体 $\alpha(\operatorname{PPAR} \alpha)$, 脂 質代謝関連酵素である FAS，アシル CoA オキシダ 一ゼ(ACOX), ミトコンドリアグリセロール-3-リン 酸アシルトランスフェラーゼ(mtGPAD)において $\mathrm{CO}$ 群と LV 群の間に有意差は見られなかった (Table 6).
Table 6. 肝臓 mRNA 発現量 の相対比較

\begin{tabular}{|c|c|c|}
\hline $\begin{array}{l}\text { Arbitrary unit } \\
\text { (each mRNA/36B4) }\end{array}$ & $\mathrm{CO}$ 群 & LV群 \\
\hline SREBP-1c & $1.00 \pm 0.22$ & $0.78 \pm 0.34$ \\
\hline FAS & $1.00 \pm 0.12$ & $0.75 \pm 0.28$ \\
\hline PPARa & $1.00 \pm 0.20$ & $0.76 \pm 0.08$ \\
\hline ACOX & $1.0 \pm 0.34$ & $0.79 \pm 0.33$ \\
\hline mtGPAD & $1.00 \pm 0.13$ & $0.88 \pm 0.23$ \\
\hline TNF- $\alpha$ & $1.00 \pm 0.56$ & $0.89 \pm 0.45$ \\
\hline $\mathrm{p} 40^{\text {phox }}$ & $1.00 \pm 0.54$ & $0.91 \pm 0.28$ \\
\hline $\mathrm{p} 47^{\text {phox }}$ & $1.00 \pm 0.15$ & $0.82 \pm 0.69$ \\
\hline $\mathrm{p} 67^{\text {phox }}$ & $1.00 \pm 0.15$ & $1.06 \pm 0.25$ \\
\hline \multicolumn{3}{|c|}{ 数値は平均值 \pm SDで表した。 } \\
\hline \multicolumn{3}{|c|}{$\mathrm{CO}$; コントロール, LV ; ロイシン+バリン } \\
\hline \multicolumn{3}{|c|}{ TNF-a:腫瘍壊死因子-a } \\
\hline \multicolumn{3}{|c|}{ SREBP-1c:ステロール調節エレメント結合たんぱく質-1c } \\
\hline \multicolumn{3}{|c|}{ PPARa:ペルオキシゾーム増殖阂応答性受容体a } \\
\hline \multicolumn{3}{|c|}{ FAS:脂肪酸合成酵素 } \\
\hline \multicolumn{3}{|c|}{ AOOX:アシルCOAオキシダーゼ(ACOX) } \\
\hline
\end{tabular}

肝臟の酵素活性は，FAS で有意差は見られなか ったが, ACOX は CO 群と比べて LV 群で有意に高 值を示した(Table 7).

Table 7. 肝臓 FAS, ACOX の比活性( $\mathrm{n} \mathrm{mol} / \mathrm{min} / \mathrm{mg}$ protein)

\begin{tabular}{lcc}
\hline & CO群 & LV群 \\
\hline FAS & $16.61 \pm 2.35$ & $16.96 \pm 1.51$ \\
ACOX & $2.26 \pm 0.77$ & $3.60 \pm 0.86^{*}$ \\
\hline 数值は平均值 $\pm S D$ SD表した。 & \\
*CO群と比べて有意差あり(p<0.05) & \\
CO ; コントロール, LV ; ロイシン+バリン &
\end{tabular}

\section{4. 考察}

本研究は，食餌性肥満モデルマウスにおける BCAA の肝臓脂質蓄積および軽度炎症に及ぼす効 果について検討を行うことを目的とした.

肝臓重量に有意差はなかったが，肝臓トリグリ セリド蓄積量は LV 群で有意に蓄積が抑制された。 最終体重および各脂肪組織重量に有意差は見られ なかったことから，ロイシンおよびバリンは肝蔵 にのみ脂質の蓄積抑制作用を示す可能性がある。

Nairizi ら[2]は，BCAA やロイシンを含有させた水 を摂取させることにより，高脂肪食による体重増 加を抑制すると報告している，本研究は飲料中で はなく飼料中に添加したため, Nairizi らとは異な る結果になったと考えられる。

さらに，脂肪酸合成酵素である FAS および分解 酵素である ACOX の酵素活性を測定すると，FAS において有意差は見られなかったが，ACOX では LV 群が CO 群に比べ有意に高值であった。ACOX は PPAR $\alpha$ によって調節され, アシル CoA を不飽 和化するペルオキシソーム酵素である[9]. 一方, 
肝臓 mRNA 発現量を測定した結果，脂質合成に関 する SREBP-1c およびFAS, $\beta$ 酸化に関わる PPAR $\alpha$ および ACOX に有意差は見られなかった。また， ミトコンドリアでの $\beta$ 酸化に関わる mtGPAD の発 現も有意差は見られなかった。 Arakawa ら ${ }^{[10]}$ 高脂肪食を与えたマウスにおいて BCAA を飲料水 に混ぜ，その影響を検討したところ，肝臓および 筋肉において PPAR $\alpha$ およびACOX1 の発現が有意 に増加したという報告をしており，我々の研究の 結果と一致しない。しかしながら， mRNA と酵素 活性の両方を測定した報告は少ない。また，絶食 時間により脂肪酸合成酵素の mRNA 発現と酵素活 性が一致しない場合もある。

また，炎症マーカーである TNF- $\alpha, \mathrm{NADPH}$ オキ シダーゼのサブユニットの mRNA 発現量に有意差 は認められなかった. NAFLD は肝臓にトリグリセ リドが蓄積し，活性酸素の発生などが要因となり TNF- $\alpha$ や IL-6 といった炎症性サイトカインが放出 されることで炎症が惹起される[11]. しかし，本研 究では TNF- $\alpha$ 発現量に有意差は見られず, 活性酸 素を産生する NADPH オキシダーゼのサブユニッ 卜発現量にも変化が見られなかった。

BCAA について, Iwasa ら[6]は, 四塩化炭素によ って肝硬変を誘導したラットにおいて，抗酸化作 用を有するたんぱく質の発現増加および活性酸素 の減少により，酸化ストレスを軽減させたと報告 した。しかし, 本研究では NADPH オキシダーゼ のサブユニット発現量に変化はなかったことから 活性酸素の産生量には影響しないと考えられたた め, Iwasa らの報告と一致しない。そのため, ロイ シンとバリンの強化によってトリグリセリドの蓄 積は抑制できたが，BCAA では炎症の抑制には影 響しなかったことが考えられた。

以上の結果から，ロイシンおよびバリンは抗炎 症作用について効果は認められなかったが, ACOX の酵素活性を高めることでペルオキシソー ムでの $\beta$ 酸化を活性化させ，肝臓脂質の蓄積を抑 制する可能性が示された。

今後は，バリンおよびロイシンの有効投与量や， 単独投与でも酵素活性を高め脂質蓄積抑制作用を 有するのか，また酵素量について影響は見られる のかを検討する予定である。

\section{引用文献}

[1]Hong, S.O. et al. Effects of leucine on in vitro protein synthesis and degradation in rat skeletal muscle. J. Nutr. 1984, 114, p.1204-1212.

[2]Zhang,Y. et al. Increasing dietary leucine intake reduces diet-induced obesity and improves glucose and cholesterol metabolism in mice via multimechanisms. Diabetes.2007, 56(6), p.1647-1654.

[3]Nairizi, A. et al. Leucine supplementation of drinking water does not alter susceptibility to diet-induced obesity in mice. J.Nutr. 2009, 139(4), p.715-719.

[4]Macotela, Y. et al. Dietary leucine-an environmental modifier of insulin resistance acting on multiple levels of metabolism. PLoS ONE.2011, 6(6), e21187.

[5] Nishimura, J. et al. Isoleucine prevents the accumulation of tissue triglycerides and upregulates the expression of PPARalpha and uncoupling protein in diet-induced obese mice. 2010. J Nutr. 140(3), p.496-500.

[6]Iwasa, M. et al. Branched-chain amino acid supplementation reduces oxidative stress and prolongs survival in rats with advanced liver cirrhosis. PLOS ONE. 2013, 8(7), e70309.

[7]Kelley, D. S.et al. Biochemical effect of prior nutritional status on the activity of lipogenic enzymes in primary monolayer cultures of rat hepatocytes. Biochem. J. 1986, 235, p.87-90.

[8]Hashimoto, T. et al. alpha-Amanitin inhibits the oxidation of long chain fatty acids in mouse liver. Biochem. J.1981, 90, p.415-421.

[9]Lemieux, I. et al. 16-week fenofibrate treatment increases LDL particle size in type IIA dyslipidemic patients. Atherosclerosis. 2002, 162, p.363-371.

[10]Arakawa, M. et al. The effects of branched-chain amino acid granules on the accumulation of tissue triglycerides and uncoupling proteins in diet-induced obese mice. Endocrine J. 2011, 58 (3), p.161-170.

[11]Furukawa, S. et al. Increased oxidative stress in obesity and its impact on metabolic syndrome. J. Clin. Invest. 2004, 114(12), p.1752-1756. 


\section{Abstract}

Recent interest was forced on non-alcoholic fatty liver disease (NAFLD) related to the metabolic syndrome. The prevalence of NAFLD in Japan is increasing and estimated as about $30 \%$. Branched chain amino acids (BCAA) has been reported to promote skeletal muscle synthesis, and suppressive effects of organ lipid accumulation has been also reported. The aim of this study is to estimate the effects of BCAA on the liver lipid accumulation and proinflammation in diet-induce obesity mice. Five-week old male C57BL/6J mice fed a high fat diet (50 energy \% by lard) and test diet containing 20\% casein (CO as control), 12\% leucine and 5\% valine mixture (LV) for 12 weeks. Liver triglyceride accumulation was significantly decreased in the LV group. Significant differences between CO and LV group were not observed in mRNA expression of TNF-alpha and a subunit of the NADPH oxidase enzyme, which is proinflammatory markers, and lipid metabolism-related enzymes were not observed. Acyl-CoA oxidase (ACOX) activity was significantly higher in the LV group compared with the $\mathrm{CO}$ group, whereas the activity of FAS was not significantly different. These results suggest that leucine and valine suppresses liver lipid accumulation through the activate in of the ACOX.

（受付日：2017 年 1 月 18 日，受理日：2017年 3 月 21 日）

工藤 陽香 (くどう はるか)

現職 : 大妻女子大学大学院人間文化研究科博士後期課程 3 年

大妻女子大学大学院人間文化研究科博士後期課程 3 年在学中.

専門は栄養生化学. 